\title{
URBAN MOBILITY AND QUALITY OF PUBLIC SPACES: THE CASE OF GRANADA, SPAIN
}

\author{
ALEJANDRO L. GRINDLAY ${ }^{1 *}$, GABRIELA OCHOA-COVARRUBIAS ${ }^{2 \dagger} \&$ CARMEN LIZÁRRAGA $^{3 *}$ \\ ${ }^{1}$ Department of Urban and Regional Planning, University of Granada, Spain \\ ${ }^{2}$ Habitat and Urban Development Department, ITESO, Jesuit University of Guadalajara, Mexico \\ ${ }^{3}$ Applied Economics Department, Faculty of Business and Economics, University of Granada, Spain
}

\begin{abstract}
Different forms of urban mobility have very different impacts on the urban environment and on the quality of the public spaces around them, from the "soft" pedestrian walkways and cycle paths, through the several modes of public transport to the extremely impactful mass use of private vehicles. This paper first analyses the different urban impacts of these forms of mobility, according to their characteristics, with regard to an extensive transport literature review, and they are put into relationship with the factors promoting urban quality and liveability in line with literature on urban design in terms of activity, image and form, among others. The results of this study are contrasted with the experience demonstrated in the case of Granada's metropolitan area, with its fairly adequate bus-based public transport system and the common mobility problems resulting from a high level of private vehicular use, i.e. congestion coupled with severe environmental pollution. However, a new light rail system (LRT) has been developed, with a major urban renewal along its track, and has proved to be very successful, in terms of the number of passengers, after its two years of operation. The LRT has the particularity of having an underground section, with three underground stations, and longer surface stretches with different cross sections, whereby the improvement in quality of public spaces along them can be evaluated. The high quality public spaces are those with no vehicular access whatsoever, providing a completely pedestrianized area, such as in the traditional urban road crossing axes in the towns, which have been completely freed from vehicles and now seem filled with people, for example Royal Street in Armilla, "Jacobo Camarero" Street in Albolote and "Blas de Otero" Avenue in Maracena, and the section along the university central campus which has no catenary.
\end{abstract}

Keywords: public transport system, sustainable mobility, urbanity, vitality, urban sustainability, LRT, Granada.

\section{INTRODUCTION}

There is a complex relationship and interaction between the urban system and the transportation system. As Vuchic [1] recognizes "transportation has a major impact not only on the physical form of cities but on their liveability - the quality of their natural and manmade environments". This interaction between the two systems has usually been described in terms of land use and changes in activity patterns transformed by the extended accessibility engendered by the transport network, and this interaction has long term impacts [2]-[4]. The objective of this paper is to analyse the implications of this purportedly symbiotic relationship [5], examining the role of the public transport system in the quality of urban public spaces and applying this to the case of Granada's metropolitan area.

Naturally, different forms of mobility impact on the urban space in different ways. From a spatial perspective, public transport systems tend to concentrate activities around their stops, and private vehicle infrastructures cause them to spread over the suburban territory [1]. Therefore, instead of the uniform urban sprawl produced by private vehicles, public transport

\footnotetext{
* ORCID: http://orcid.org/0000-0001-5176-0550

† ORCID: http://orcid.org/0000-0002-2864-6634

* ORCID: http://orcid.org/0000-0002-3221-6178
} 
has led to a polycentric urban form, reinforced through decentralisation and centralization forces [5]. The concentrated accessibility of transits affects land use, increasing land rents and promoting higher density developments [2]. With regards to the urban environment, the increasing car use in cities is widely and traditionally recognized as an essential cause of the deterioration of living conditions and the exacerbation of environmental problems [4], [6]. In contrast, public transport systems by their very nature are more sustainable, due to their relative social, economic and environmental performances, than private vehicle-based transport systems [7], [8].

The broadly recognized urban patterns linked to sustainable mobility, according to Williams [9], move away from functional land use zoning and reduce urban sprawl, by creating the "contained" and compact, urban layouts, with a mix of uses in close proximity, reducing travel demand and making use of local services and facilities. Therefore, sustainable urban forms also promote sustainable mobility and vice-versa, as high densities provide enough population to support public transport services and an adequate urban design encourages cycling and walking [4]. In addition, higher-density land use - including population and employment - improves the sustainability of public transport systems [8]. Reciprocally, sustainable transport solutions, especially those involving high investment levels, such as improvements in public transport services, will have a significant urban impact [1], [4], [7]. As stated in the Leipzig Charter on Sustainable European Cities [10] an "essential contribution to the quality of life, locational quality and the quality of the environment can be made by sustainable, accessible and affordable urban transport with coordinated links to the city-region transport networks".

In recent decades there have been many examples all over the world revealing that a reduction in the level of private vehicular use in cities and in their occupation of the urban space, accompanied by high quality public transport services, leads to improvements in highquality urban environment and life. They have been explained and described by Gehl [11], and demonstrated through other successful initiatives promoting pedestrian-oriented areas at the expense of space for cars [12], [13]. In addition, this vehicle restriction is particularly necessary in high automobile-oriented areas, not only to alleviate pollution emissions but also to guarantee the positive effects of new public transit systems. However, the most positive benefits of these systems are achieved through integrating transport and urban or land use planning [2], [4].

The recent "lockdown" due to the coronavirus pandemic has manifestly demonstrated the harm to the air quality of our cities caused by the intense traffic, and how clean the air could be without such traffic, and this has been widely recognized during the last few weeks [14], [15].

According to the current shift towards a sustainable urban mobility [7] and urban sustainability [16], strong links can be identified between the detailed spatial characteristic of an urban sustainable model, according to its assessment model attributes and characteristics [17], the objectives of urban planning linked to a sustainable mobility [18], and the principles to remodel our cities favouring liveability as stated by ITDP [19]. In particular, the relevance is shown of supporting a high-quality public transport system, ensuring frequent, fast and direct transit services, and locating transit stations, homes, employment and services within walking distance of each other, to make sustainable modes of transport the most attractive.

The sustainable urban model is a compact city in its morphology, complex in its organization, metabolically efficient and socially cohesive [16]. Therefore, public transport development affects all dimensions of urban sustainability, as it transforms city morphology, and is linked to its energy efficiency and its social cohesion. So, in this relationship between 
the sustainability of the urban and transportation/mobility systems to attain urban liveability, the quality of the public transport system, facilitating walking and cycling and attempting to be more attractive than motorized private transport, is very relevant.

Thus, it is valuable to analyse the role of the public transport system in the quality of urban public spaces in relation to the literature on urban design. Following these considerations, different sustainability levels will be defined for different street sections, and they will be applied to the case of Granada's metropolitan area and its new light rail transit (LRT).

\section{PUBLIC TRANSPORT SYSTEMS PROMOTING URBANITY, VITALITY AND URBAN SUSTAINABILITY}

There is a global and continuous renaissance of urban public transport systems. According to McLeod et al. [20], there has also been a broad consensus among researchers for what constitutes "best practice" in this system design, such as "intermodal connectivity, provision of high-quality services, clear strategic congruency, and integration of transportation and land use policies", and these continue "as unambiguous principles in contemporary transport planning practice".

However, the question is: in what respect does a public transport system impact on the urban environment and the improvement of the quality of the urban space? As has been considered, it has a significant capacity in "placemaking" [21] and, according to Chen [5], "for Peter Hall, the relationship between transport and development is interwoven and inseparable in creating an overall vision of good cities for better lives".

Those transportation elements which promote and/or increase urbanity and vitality, can be considered as most distinctive characteristics of cities, and also those promoting urban sustainability. According to Montgomery [22], there are three essential urban dimensions linked to urbanity: "activity, image, and form". This author proposes that these are achieved through different principles. In addition, there are some basic conditions for achieving urban vitality, which were described by Jane Jacob in the Sixties and were recently charted in Barcelona [23], listed as: "concentration, diversity, contact opportunity, need for aged buildings, accessibility and distance to border vacuums". They are also linked to the cited principles, and both are basic references in urban design literature.

The consideration of these principles and conditions of urban design allows for an understanding of how public transport systems promote urbanity and vitality in cities, in the clear correlation existing between them. However, there is also an evident similarity with those conditions related to the sustainability of the urban and mobility systems. Vitality conditions are related to physical principles of "activity and form", but transport systems also affect the "image" principles.

With regards to these principles, which are widely explained in the indicated references, the increased urban activity derived from the growing number of passenger flows around the new stops or stations is clearly linked to principles (1) "generating pedestrian flows and vitality", (2) "seeding of people attractors" and (6) "promoting street life and peoplewatching". These are connected with the vitality conditions of "accessibility" and "contact opportunity". In addition, as has been indicated, public transport systems require and promote population and employment density [2], therefore they are linked to the principles (4) "developing a density of population" and (14) "achieving development intensity", related with the vitality condition of "concentration", and usually they are associated with new urban developments requiring "zoning for mixed use" as indicated by principle (15) and associated with a necessary "diversity" for vitality conditions.

Public transport systems are developed in conjunction with the physical transformation of the urban space environment improving pedestrian areas, which is obviously linked to the 
principles related to public space: (21) "the public realm", (22) "movement", (23) "green space and water space" and (24) "landmarks, visual stimulation and attention to detail".

Lastly new public transport systems generally have an image of modernity, therefore improving the urban image, which is linked to principles (8) "legibility", (9) "imageability", (11) "psychological access", (12) "receptivity", (13) "knowledgeability", and then, from different perspective, with historic systems (10) "symbolism and memory" [22].

On the other hand, one of the most important factors in the urban effects of public transportation is its spatial efficiency in the occupancy of urban space with respect to other transportation modes [1]. There are multiple examples of urban space recovery.

However, the inherent potential of urban public transport to change cities will vary in each context according different factors "of reproduction and dependency: technical, morphological, political and institutional", giving different levels of recognized success [24].

Among the different forms of public transport modes, rail-based modes, due to their heavier physical characteristics and permanence, have been revealed as having a greater and longer impact on urban areas [25], particularly in comparison with bus-based transport systems such as bus rapid transit [21].

The LRT in particular, as a fully independent transit system, is considered by Vuchic as the superior public transit mode that can enhance the human orientation of cities and "usually has a major impact on the downtown of the core city, as well as on the outlying towns and subcenters it serves". It is judged much more attractive to passengers than buses, and is superior to them in reliability of service, "riding comfort, vehicle performance, system image, and other qualities that the electric traction of LRT offers: quiet operation, absence of air pollution, the ability to operate in tunnels. In pedestrian malls and other people-oriented areas, LRT is accepted much more readily than diesel-powered buses" [1].

Consequently, there is an increasing number of examples of cities developing rail transit systems all over the world [26]. However, the case of French tramways and their urban redevelopment [27] is one of the most relevant, as they have been used to promote a particular place-image and identity throughout their cities [21], and it is also the most significative reference for Spanish LRT developments, due to the vicinity to Spain.

With respect to these experiences, to avoid the more subjective interpretation of the terms used about cities regarding attractiveness, quality and liveability, Ferbrache and Knowles [21] recently analyse the relationship between light rail development and city boosterism as a place-making process. They extensively analyse the impact on the previously cited "image" principles in order to understand what light rail can do for city image and quality, reaching similar conclusions which consider "light rail as an agent in city-making". They also found that the perceptions associated with light rail and its symbolism as a modern system, can signify "progress and development, and an opportunity to boost existing ideas about a city". This modern image can also become a distinctive feature for the city's prestige.

As previously mentioned, especially in the case of the development of new LRT systems, with the integration of transport infrastructure with urban planning and land-use [4], its placemaking effect is particularly evident "as a strategy by city planners and developers towards achieving sustainability principles and more liveable cities", transforming urban areas and boosting "image and quality from small-scale street improvements to city-wide enhancement" [21].

Thus, these LRT systems have generally been developed through the renovation and promotion of the public realm. They have been constructed together with an urbanization renewal from façade to façade, developing a high-quality physical environment with pedestrian-friendly areas and the enhancement of the streetscape, attractive not only for the transit passengers but also the investors, developers and the general population. This urban 
renewal and the new high capacity mode of public transport mode are the main urban effects directly linked to the urban quality. Among these attributes it should be highlighted that LRT systems are fully-compatible with pedestrian-oriented and pedestrianized areas considering the sustainability dimensions as indicated in Table 1 [1], [2], [4], [21], [24], [27].

Table 1: Compatibility LRT-Pedestrian-oriented areas according to sustainability dimensions. (Source: Authors based on Vuchic [1] and Bertolini [4].)

\begin{tabular}{|l|l|l|}
\hline \multicolumn{3}{|c|}{ Sustainability dimensions } \\
\hline Spatial & Environmental & Social \\
\hline $\begin{array}{l}\text { Efficient and reduced } \\
\text { space occupation }\end{array}$ & No atmospheric contamination & Favours social cohesion \\
\hline $\begin{array}{l}\text { Barrier effect limited } \\
\text { according to frequency }\end{array}$ & Noise reduction & Safety perception \\
\hline Fully-accessible & Urban design and landscaping & Image of modernity \\
\hline
\end{tabular}

In order to evaluate the quality of the urban space, a spatial analysis through mapping indicators similar to the methodology applied in Barcelona [23] could be proposed, and different methodologies developed and applied in other cities [28], mainly from social indicators research. However, taking into account the correspondence between the model of urban sustainability and the sustainability of its model of mobility, which has already been demonstrated, it could also be considered, as a first simple approximation, that the public space quality of the streets is intrinsically linked to the grade of sustainable mobility that is happening in their environs. Therefore, following the current guidelines of sustainable mobility planning [29], [30], an easy analysis of the sustainable mobility level of the streets according to their existing cross sections is proposed. Then, the proportion of sustainable mobility areas can be easily evaluated, with regards to the areas for the "soft" modes of pedestrians and cycles, and the public transport areas, and on the other hand, the proportion of the space given to motorized vehicles as an unsustainable mobility area (Table 2). This methodology will be applied to the case of the case Granada's metropolitan area.

Table 2: Sustainable mobility levels of the proposed street cross-sections analysis.

\begin{tabular}{|c|c|c|}
\hline Sustainable mobility level & $\begin{array}{c}\text { Sustainable mobility } \\
\text { area (SMA) (\%) }\end{array}$ & $\begin{array}{c}\text { Unsustainable mobility } \\
\text { area (UMA) (\%) }\end{array}$ \\
\hline A & 100 & 0 \\
\hline B & $80-100$ & $20-0$ \\
\hline C & $60-80$ & $40-20$ \\
\hline D & $40-60$ & $60-40$ \\
\hline E & $20-40$ & $80-60$ \\
\hline
\end{tabular}

\section{THE CASE OF GRANADA'S METROPOLITAN AREA AND ITS NEW LRT}

Granada is a city of approximately 230,000 inhabitants, surrounded by more than thirty municipalities giving an urban agglomeration of half a million inhabitants, located in the southern region of Andalusia (Spain). This area has been formed around a fertile and productive agricultural plain where, since the beginning of the last century, a complete transit system was developed. The historical tram system eventually had one hundred $\mathrm{km}$ of lines, connecting the populations and the sugar industries of the plain, transporting both passengers 
and products, and was in operation from 1904 to 1974 [31]. Its spatial structure was the basis of the later development of the metropolitan road system.

As in numerous Western cities, the public transport system had become bus-dominated and, in contrast to other European countries where many tram networks survived [20], the whole original tram system of Andalusian cities disappeared during the 1960s and 1970s under the pressure of the growing motorization. During the last decades of the twentieth century, metropolitan mobility investments traditionally favored the automobile infrastructure over the mass transport option, which has meant that, in recent years, the participation of private means of motorized transport in daily mobility is very much in the majority (79\%), as opposed to journeys on foot or by bicycle (13\%) and those made by public transport which scarcely make up $8 \%$ of journeys [6].

In recent decades Andalusia's mobility policy has pivoted around the three axes of coordination, planning and investment: coordination, through the creation of metropolitan transport authorities, as embodied by the consortiums existing in the principal metropolitan areas of Spain; planning, through the drafting and implementation of territorial spatial plans and sustainable mobility plans; and investment in new infrastructure and rail-based public transport services. Granada's metropolitan transport authority was established in 2003, and its territorial spatial plan, which was the first metropolitan spatial plan of the region, was previously approved in 2000, proposing both this consortium and a modern rail-based public transport system to solve their mobility problems [32], [33]. Metropolitan and urban sustainable mobility plans were also drafted in 2008 and 2012 respectively [6].

During the 1990s, the growing experiences of rail transit system developments in Europe over the preceding decades [25] drew the attention of the Spanish authorities studying the possibilities of LRT to provide new trams in the city to improve accessibility, urban mobility, the urban environmental quality and the public transport system, as well as promoting urban renewal [34]. Therefore, new tram systems were developed in some of the major Spanish cities, as successful experiences of urban renewal [35].

Later the regional authorities of Andalusia who studied LRT cases and construction costs concluded that it was an excellent solution, for urban integration in historical centres, and for urban transformation of degraded areas as well as for integral re-urbanization between facades, not to mention the advantages of accessibility, safety, efficiency and energy sustainability and of their modern image [36]. Due to their established benefits (the increase of displacement speed, the reduction of traffic congestion, $\mathrm{CO}_{2}$ emissions at a rate 50 times lower than the private vehicle, since their capacity equals almost two hundred cars or three buses, higher safety, plus aesthetic and functional benefits), and the existing experiences in other cities, Andalusia's government has promoted and developed new LRT systems in their main metropolitan areas of Seville, Malaga, Cadiz, and Granada [33].

Construction of Granada's metropolitan LRT began in 2007 and, due to the last economic crisis, works were extended for ten years. Thus, the system started operation in September of 2017, and almost reached the expected numbers of passengers (eleven million) during the first year in service [37]. Following the cited successful French experiences [27], parts of the technical projects were drafted by French engineering consulting firms. These projects focused on the LRT's high urban integration capacity and its extraordinary transformational potential, developing a significant urban renewal from façade to façade along its $16 \mathrm{~km}$, covering 718,984 square meters, with $8,913 \mathrm{~m}$ of new bike lanes and almost 3,000 new trees. It also constitutes a new mode of public transport mode favoring intramodality with the connection of bus and railway stations [38].

With respect to Section 1, from the mobility system perspective, this new LRT has radically improved the quality of the existing bus-based public transport system, but has also 
signified a great urban change along its corridor, contributing to increased pedestrian mobility, and reducing car usage in the areas served, and there are some tracks without catenary, almost completely free of cars and their visual intrusion. Analyzing this new LRT system with reference to Section 2, in line with the Montgomery principles [22] and vitality conditions [23], urban activity has clearly increased due to the growing number of passengers around the new stations and the new metropolitan accessibility. The main stations are the most central and attractive, such as "Recogidas" and "La Caleta" with more than 1.3 and 0.8 million users respectively [37], [39]. As previously mentioned, this is fully linked with the principles (1) "generating pedestrian flows and vitality", (4) "developing a density of population", and (6) "promoting street life and people-watching". The new stations and vehicles have been carefully designed to create an image of modernity [38] and therefore improve the general urban image, which is linked to the principles (8) "legibility", (9) "imageability", (10) "symbolism and memory" (in reference to the historical tram), (11) "psychological access", (12) "receptivity", and (13) "knowledgeability", as has also been shown in many other cases [21]. Lastly the urban space configuration has been transformed, that is, in relation to the principles (21) "public realm", and (22) "movement".

An evaluation, carried out by the authors through a spatial analysis of the urban cartography of the city of Granada, shows that the street transformation promoted by the new LRT along its corridor has given an increase of pedestrian surface from 210,444 (in 2004) to 320,306 square meters (in 2017). This new urbanization clearly demonstrates a great improvement in the quality of pedestrianisation around the stations, but in some areas there is still room for improvement, as some areas, which have a different cross section, are more motorized mobility-oriented, and even these different levels of quality, according to urban design criteria, will give different accessibility levels to the LRT stations [40].

As its initial passenger success shows [37], [39], its corridor was correctly selected along the densest areas of the metropolitan north-south axis to attract high levels of initial transit ridership, and to alleviate the most congested metropolitan route [1], [2].

During its planning phase, the new LRT had a discussion process between local and regional authorities about surface or underground sections, and several research groups from the local University asked the question with a report. Our group headed by Prof. Gómez Ordóñez attested to the urbanistic opportunities of burying the central section of the metropolitan line [41]. Consequently, the agreement between these two administrations led to the particularity of having a $3 \mathrm{~km}$ underground central section, with three underground stations of high architectural quality, one of them "Alcazar Genil" has received architectural awards for its integration of archaeological Arab remains found on the site [38], ultimately confirming its adherence to the principle of "urban strength". However, some potential opportunities to integrate this transport infrastructure with urban planning and land-use have not been considered or achieved [41].

The subterranean section makes the LRT transport system independent from the urban system, and so is able to reach the maximum commercial speed; however, the surface street section is relatively conventional in its design, but also reformed, giving more space to the pedestrian area and a new cycle lane. There are few comparisons between surface and subterranean LRT sections, as the first will have linear urban effects and in the subterranean section the effects will be concentrated around the stations, which have been widely studied by the node-place model [4]. As has been studied in Hong Kong, in choosing between tram and metro, scenery and emotional attachment seems to be significant in the choice of tram for the same trips [42], and the tram also contributes greatly to street vitality [43].

Along its surface sections, the higher quality public spaces are those with no private vehicular access whatsoever, providing a completely pedestrianized area, such as in the 
traditional urban road crossing axes in the towns, which have been completely freed from vehicles and now seem filled with people, such as Royal Street in Armilla, "Jacobo Camarero" Street in Albolote and "Blas de Otero" Avenue in Maracena, and the section along the university central campus which has no catenary [38]. In addition, after two years in service, it has been calculated that the new system has avoided 5.36 million trips by car and has helped to avoid 5,420 tons of $\mathrm{CO}_{2}$ emissions [39].

However, the general metropolitan congestion levels in Granada remain high and the pollution levels in the area are still worrying because, among others, the urban and metropolitan sustainable mobility plans have not been fully implemented [6]. In fact, despite having less dense traffic than in Madrid and Barcelona, its pollution problems are similar as they are exacerbated by geography and climate conditions, since the area is located in a valley surrounded by mountains that trap the pollution in winter [44].

Analyzing the sustainable mobility level of the metropolitan streets considering their existing cross sections, or inversely the predominance of motorized vehicles in the urban space, almost all metropolitan streets and avenues are of conventional urban design and are compatible with motorized vehicle access, giving sections with moderate to high traffic space (C-E), except the commercial pedestrianized urban central and historical areas, urban parks, and the indicated LRT corridor, with A-B levels of sustainable mobility. This is shown in Fig. 1. In order to clarify further, only the analysis along the new LRT corridor is shown, where section A indicates plenty of sustainable mobility areas, and therefore urban spaces of high-quality and, at the other end of the scale, section E designated as being fully motorized vehicles-oriented areas with LRT line but with no pedestrian access.

However, urban space can be configured in a very flexible way, and it can be changed relatively quickly by restricting access to private vehicles simply with new street signalling, as has been shown in the cited examples [10], [11]. Currently, social distancing required by the COVID pandemic has meant that many cities are giving more space in their streets to

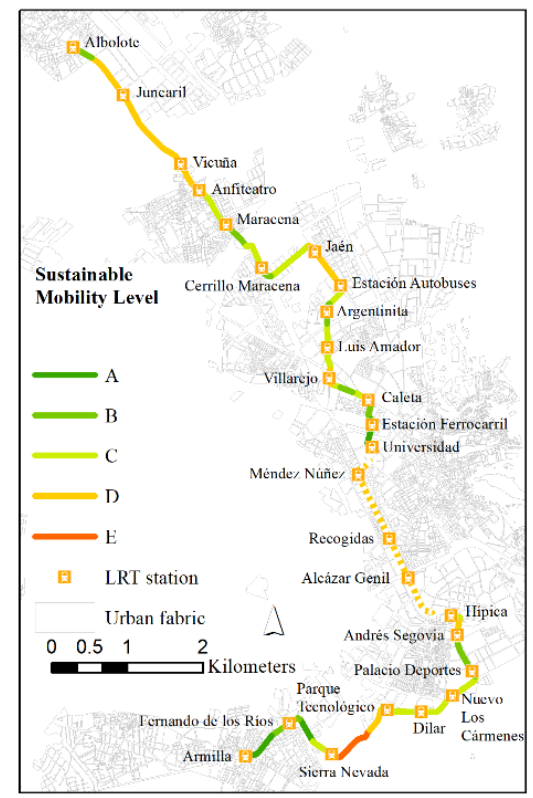

Figure 1: Sustainable mobility levels along the metropolitan LRT of Granada. 
sustainable mobility modes, and Granada is no exception, increasing pedestrianized areas and spaces for bicycles and other personal mobility modes (thus the street over the underground LRT section will now change to level C) [45] and, therefore, indirectly increasing the quality of their urban space.

\section{CONCLUSIONS}

Urban systems and transportation and mobility systems are intrinsically related to one another. Their interactions are now indisputable as well as their respective links to sustainability and quality. The relevant incidence of high-quality public transport systems promoting urbanity, vitality, urban sustainability and image has also been demonstrated. In particular, given its characteristics and its full compatibility with pedestrian-oriented areas according to sustainability dimensions, LRT can be considered as the superior public transit mode, enhancing the human orientation of cities.

It is possible to construct indicators for spatial models to evaluate both systems, but a simple space analysis would be recommended as a first approximation to this complex reality. Thus, given the inherent correspondence between the models of urban and mobility sustainability, grading the level of the sustainable mobility space of streets is proposed in order to easily evaluate the quality of the urban space, taking into consideration the proportion of existing sustainable mobility areas in the cross sections of the streets in question.

The development of a new LRT system in the metropolitan area of Granada, having a fully bus-based public transport system, and applying all of its potential for urban renewal, is a good example of improved sustainable mobility and of the increase in the urban quality of its streets as public space. Having surface and underground sections allows an assessment of its different interactions between urban and transport systems.

However, despite creating a significant increase in the space given to pedestrians and bicycles along its corridor, the majority of the metropolitan street systems are of a conventional urban design, giving high prominence to motorized vehicular access, and reducing the sustainable mobility levels. Therefore, the higher quality areas will be limited to only a few completely pedestrianized central areas and the rest of its corridor will be motorized mobility-oriented areas, giving less urban quality along their route. In addition, some potential opportunities for the integration of transport infrastructure with urban planning and land-use will not be considered or achieved.

The sustainability of the metropolitan mobility system has improved and an appreciable part of the urban space has been reshaped and revitalized, despite its conservative cross sections, but this is not enough to solve their serious environmental problems resulting from its highly polluting motorized transport system.

The current COVID19 crisis has led to a substantial yet temporary reduction in the pollution caused by the urban transport system and has revealed the need for increasing urban space for sustainable mobility modes to allow social distancing.

ACKNOWLEDGEMENT

With thanks to Politecnico di Torino Civil Engineer, Giovanna Luigia Reccia, for her help in the analysis.

\section{REFERENCES}

[1] Vuchic, V.R., Transportation for Livable Cities, Routledge: London and New York, 2017. 
[2] Higgins, C., Ferguson, M. \& Kanaroglou, P., Light rail and land use change: Rail transit's role in reshaping and revitalizing cities. Journal of Public Transportation, 17(2), pp. 93-112, 2014.

[3] Kasraian, D., Maat, K., Stead D. \& van Wee B., Long-term impacts of transport infrastructure networks on land-use change: an international review of empirical studies. Transport Reviews, 36(6), pp. 772-792, 2016. https://doi.org/10.1080/01441647.2016.1168887.

[4] Bertolini, L., Planning the Mobile Metropolis: Transport for People, Places and the Planet, Macmillan International Higher Education: London, 2017.

[5] Chen, C.L., Transport and place-making: A long view. Sir Peter Hall: Pioneer in Regional Planning, Transport and Urban Geography, Springer: Cham., pp. 37-58, 2016.

[6] Grindlay, A.L., Molero, E., Miralles-Guash, C. \& Lizarraga, C., Environmental impacts of everyday mobility in Andalusia (Spain): Towards a sustainable scenario? WIT Transactions on Ecology and the Environment, vol. 194, WIT Press: Southampton and Boston, pp. 373-384, 2015. http://dx.doi.org/10.2495/SC150331.

[7] Banister, D., Unsustainable Transport: City Transport in the 21 st Century, Routledge: London, 2005.

[8] Currie, G. \& De Gruyter, C., Exploring links between the sustainability performance of urban public transport and land use in international cities. Journal of Transport and Land Use, 11(1), pp. 325-342, 2018. http://dx.doi.org/10.5198/jtlu.2018.957.

[9] Williams, K., Spatial planning, urban form and sustainable transport: An introduction. Spatial Planning, Urban Form and Sustainable Transport, ed. K. Williams, Ashgate: Farnham, pp. 1-13, 2005.

[10] EU, Leipzig Charter on Sustainable European Cities, 2007. http://ec.europa.eu/ regional_policy/archive/themes/urban/leipzig_charter.pdf. Accessed on: 20 Jan. 2020.

[11] Gehl, J., Cities for People, Island Press: Washington, 2010.

[12] ARUP, Cities Alive: Towards a Walking World, 2016. www.arup.com/perspectives/ publications/research/section/cities-alive-towards-a-walking-world. Accessed on: 2 Feb. 2018.

[13] Bendiks, S. \& Degros, A., Traffic Space is Public Space. A Handbook for Transformation, Park Books: Zurich, 2019.

[14] Watts, J. \& Kommenda, N., Coronavirus pandemic leading to huge drop in air pollution. The Guardian, 23 Mar. 2020. www.theguardian.com/environment/2020/ mar/23/coronavirus-pandemic-leading-to-huge-drop-in-air-pollution. Accessed on: 26 Mar. 2020.

[15] Regan, H., Air pollution falls by unprecedented levels in major global cities during coronavirus lockdowns. CNN, 23 Apr. 2020. https://edition.cnn.com/2020/04/22/ world/air-pollution-reduction-cities-coronavirus-intl-hnk/index.html. Accessed on: 24 Apr. 2020.

[16] Ministerio de Fomento, Guía Metodológica para los Sistemas de Auditoría, Certificación o Acreditación de la Calidad y Sostenibilidad del Medio Urbano, Centro de Publicaciones, Secretaría General Técnica, 2012.

[17] Martí P., Nolasco-Cirugeda, A. \& Serrano-Estrada, L., Assessment tools for urban sustainability policies in Spanish Mediterranean tourist areas. Land Use Policy, 67, pp. 625-639, 2017. https://doi.org/10.1016/j.landusepol.2017.06.015. 
[18] Sanz Alduan, A., Urbanismo y Movilidad Sostenible. Guía para la construcción de ciudades siguiendo criterios de movilidad sostenible, NASURSA Navarra de Suelo Residencial, S.A., 2010. www.crana.org/themed/crana/files/docs/147/236/promotion guiaurbanismo_sintesis.pdf. Accessed on: 20 Jan. 2012.

[19] Institute for Transportation and Development Policy (ITDP), Our cities ourselves: Principles for transport in urban life, 2011. www.itdp.org/2011/08/29/our-citiesourselves-principles-for-transport-in-urban-life/. Accessed on: 20 Jan. 2012.

[20] McLeod, S., Scheurer, J. \& Curtis, C., Urban public transport: Planning principles and emerging practice. Journal of Planning Literature, 32(3), pp. 1-17. https://doi.org/10.1177/0885412217693570.

[21] Ferbrache, F. \& Knowles, R.D., City boosterism and place-making with light rail transit: A critical review of light rail impacts on city image and quality. Geoforum, $\mathbf{8 0}$, pp. 103-113. 2017. http://dx.doi.org/10.1016/j.geoforum.2017.01.013.

[22] Montgomery, J., Making a city: Urbanity, vitality and urban design. Journal of Urban Design, 3(1), pp. 93-116, 1998. http://dx.doi.org/10.1080/13574809808724418.

[23] Delclòs-Alió, X. \& Miralles-Guasch, C., Looking at Barcelona through Jane Jacobs's eyes: Mapping the basic conditions for urban vitality in a Mediterranean conurbation. Land Use Policy, 75, pp. 505-517, 2018.

https://doi.org/10.1016/j.landusepol.2018.04.026.

[24] Pflieger, G., Kaufmann, V., Pattaroni, L. \& Jemelin, C., How does urban public transport change cities? Correlations between past and present transport and urban planning policies. Urban Studies, 46(7), pp. 1421-1437, 2009. https://doi.org/10.1177/0042098009104572.

[25] Chen, C.-L., Wider Impacts of Rail-Based Transport Investment on Urban and Economic Development: Literature Review, EU INTERREG 4B SINTROPHER Project London, Bartlett School of Planning, University College, London, 2014.

[26] Shyr, O.F., Andersson, D.E., Cheng, Y.H. \& Hsiao, Y.H., What explains rapid transit use? Evidence from 97 urbanized areas. Transportation Research Part A: Policy and Practice, 100, pp. 162-169, 2017. http://dx.doi.org/10.1016/j.tra.2017.04.019.

[27] Boquet, Y., The renaissance of tramways and urban redevelopment in France. Miscellanea Geographica, 21(1), pp. 5-18, 2017. https://doi.org/10.1515/mgrsd-2017-0005.

[28] Garau, C. \& Pavan, V.M., Evaluating urban quality: Indicators and assessment tools for smart sustainable cities. Sustainability, 10(3), p. 575, 2018. https://doi.org/10.3390/su10030575.

[29] Deutsche Gesellschaft für Internationale Zusammenarbeit (GIZ), Urban mobility plans: National approaches and local practice, 2014. https://itdpdotorg.wpengine.com /wp-content/uploads/2015/06/TD13_UMP_final.pdf.

[30] Rupprecht Consult (ed.), Guidelines for Developing and Implementing a Sustainable Urban Mobility Plan, 2nd ed., 2019. www.eltis.org/sites/default/files/sumpguidelines-2019_mediumres.pdf. Accessed on: 2 Dec. 2019.

[31] Castillo Martínez, A. \& Castillo Vergara, A., Los tranvías históricos de Granada, S.E.: Granada, 2014.

[32] Consejería de Obras Públicas y Transportes (COPT), Plan de Ordenación del Territorio de la Aglomeración Urbana de Granada, Junta de Andalucía: Sevilla, 2000.

[33] Lizárraga, C. \& Grindlay, A.L., Hacia un modelo de movilidad urbana sostenible en Andalucía. Actualidad, 65. Centro de Estudios Andaluces: Sevilla, 2012. https://centrodeestudiosandaluces.es/publicaciones/n-65-hacia-un-modelo-demovilidad-urbana-sostenible. 
[34] Ministerio de Obras Públicas, Transportes y Medio Ambiente (MOPTMA), Metro Ligero. Nuevos tranvías en la ciudad, Secretaría General Técnica: Madrid, 1994.

[35] Salmerón i Bosch, C., Tranvías de España: la nueva movilidad urbana, Ed. Terminus: Barcelona, 2009.

[36] Consejería de Obras Públicas y Transportes (COPT), Metro Ligero: Iniciativas y costes de construcción, Dirección General de Transportes, Junta de Andalucía: Sevilla, 1998.

[37] Agencia de Obra Pública de la Junta de Andalucía (AOPJA), BALANCE ANUAL Metropolitano de Granada, 2018. www.aopandalucia.es/inetfiles/agencia_ estructura/622019114848.pdf. Accessed on: 1 Mar. 2019.

[38] Agencia de Obra Pública de la Junta de Andalucía (AOPJA), Presentación METRO DE GRANADA Colectivos Sociales, 2017. www.aopandalucia.es/inetfiles/agencia estructura/1732017103823.pdf. Accessed on: 2 Feb. 2018.

[39] Agencia de Obra Pública de la Junta de Andalucía (AOPJA), BALANCE ANUAL Metropolitano de Granada, 2019. www.aopandalucia.es/inetfiles/agencia_ estructura/231202010112.pdf. Accessed on: 2 Apr. 2020.

[40] Talavera García, R., Valenzuela Montes, L.M. \& Soria Lara, J.A., Evaluando la influencia de la calidad de la distancia peatonal en la cobertura de paradas del metro ligero de Granada (España). Boletín de la Asociación de Geógrafos Españoles,79(2472), pp. 1-25, 2018. http://dx.doi.org/10.21138/bage.2472.

[41] Gómez Ordóñez, J.L. et al., Informe sobre el Metro Ligero de Granada. Las oportunidades urbanísticas de la línea metropolitana $N-S$ sobre el soterramiento del tramo central, 2004. http://hdl.handle.net/10481/6559.

[42] Yang, W. \& Zacharias, J., Choosing between tram and metro in Hong Kong: Utility, affect and demographics. WIT Transactions on The Built Environment, vol. 176, WIT Press: Southampton and Boston, pp. 131-141, 2017. http://dx.doi.org/10.2495/UT170121.

[43] Zacharias, J., The Contribution of a Tramway to Street Vitality, 2018. www.researchgate.net/profile/John_Zacharias/publication/321035428_The_contribut ion_of_the_tramway_to_street_vitality-the_case_of_Hong_Kong/links $/ 5 \mathrm{a} 7 \mathrm{aa} 6 \mathrm{a} 80 \mathrm{f}$ $7 \mathrm{e} 9 \mathrm{~b} 4 \overline{1} \mathrm{dbd} 65123 /$ The-contribution-of-the-tramway-to-street-vitality-the-case-ofHong-Kong. Accessed on: 24 Apr. 2020.

[44] Sánchez, E. \& Sevillano, E.G., 15 million Spaniards are breathing air the EU considers polluted. More than half of Spain is wreathed in air containing excessive levels of particulate matter, nitrogen dioxide and ozone. El Pais, Madrid, 7 Dec. 2018. https://english.elpais.com/elpais/2018/12/05/inenglish/1544008632_514634.html. Accessed on: 14 Dec. 2018.

[45] Rodríguez, P., La capital reserva carriles para bicis y patinetes y arranca la peatonalización del centro. IDEAL, Granada, 18 May 2020. www.ideal.es/granada/ revolucion-trafico-granada-20200518114650-nt.html. Accessed on: 20 May 2020. 